\title{
The Influence of Multi - Cultural Higher Education on Economic Development
}

\author{
Hüseyin Baykan
}

\begin{abstract}
Near East University, Faculty of Bussiness and Administration, Nicosia, North Cyprus, Mersin 10, Turkey
\end{abstract}
\begin{abstract}
The aim of this study is to specify the contribution of universities and university students to social and cultural structure and economic development of the country. Representatives of public organizations, tradesmen and economic organizations were given semi-structured interview. The data were analyzed through "content analysis". The findings indicate that, students from foreign countries do not spoil the cultural structure of the country. However, due to the economic conditions in their countries, students from the third world countries are willing to stay on the island. If employed, their employment might have negative effects on the social and cultural structure of the island in long-term. Another finding revealed that the universities do not receive sufficient contributions from the state and the scholarships awarded are insufficient.
\end{abstract}

Keywords - University, Economy, Education, Economy education, Economic Development

\section{Introduction}

Educational Management is one of most rapidly developing disciplines in the world. The future of states is closely related to the education generations receive and especially the education of young generations is critical as they are the ones to shape the future [3], [4].

DOI: 10.18421/TEM101-32

https://doi.org/10.18421/TEM101-32

Corresponding author: Hüseyin Baykan,

Near East University, Faculty of Business and Administration, Nicosia, North Cyprus, Mersin 10, Turkey.

Email: huseyinbaykan.1975@gmail.com

Received: 07 November 2020.

Revised: 21 January 2021.

Accepted: 30 January 2021.

Published: 27 February 2021.

(c) BY-NC-ND (C) 2021 Hüseyin Baykan; published by UIKTEN. This work is licensed under the Creative Commons Attribution-NonCommercial-NoDerivs 4.0 License.

The article is published with Open Access at www.temjournal.com
On the island of North Cyprus, one of the leading factors of economy is the universities. "Higher Education the leading sectors of North Cyprus economy" (Higher Education Strategy and Action Plan Proposal, TRNC (Turkish Republic of North Cyprus), 2012) is an example. Universities are essential to educate individuals to provide economical productivity. Universities are the backbones of economic development because science and technology are produced in universities [10]. It is stressed that particularly in underdeveloped and developing countries establishing universities in wide rural areas will be a benefit for economy. In the global world, science and information society exists through universities as the leading institutions. Universities have important functions in criticizing societal and economic development, technological infrastructure [25], [28], transferring cultural values to young generations, providing and preserving new information [27]. The level of development and economic development of societies come about parallel to education. This is why universities have a great role in the country.

Although the basic mission of universities is to lead individual development and their intellectual lives, their economic yields cannot be ignored [12]. When education is considered as a sector, the contribution of universities to the economy is clearly observed. It is believed that there is a positive connection between the levels of economic development and level of education an individual receives. Educational economists emphasize that the main source of development is the quality and level of education individuals receive. Another benefit of education is that it has a great effect on the social, political, and economic structure and quality of people [1].

\section{Literature Review}

\section{Universities in North Cyprus}

The first university named "Lefkoşa Özel Türk Üniversitesi” Lefkoşa Turkish Private University was established in 1972 by Servet Sami Dedeçay, but it did not have an institutional identity. In the 
university magazine by Dedeçay (1983) [9] and in many other magazines Hasan Şaşmaz was a researcher- writer. Şaşmaz was a volunteer poetresearcher at our university and from time to time, he voiced poems with regard to political-social problems in his environment [7].

The first university with an institutional identity was the Higher Technological University established in Magusa in 1979. Later in 1986 it was named as Eastern Mediterranean University [19].

Table 1. The percentages of Universities according to their types from 1979 to 2016-2017 in North Cyprus

\begin{tabular}{||ccc||}
\hline \multicolumn{1}{|c}{ Type } & Number & Rate \% \\
Private & 8 & 57,13 \\
State-Vakf & 2 & 14,29 \\
Vakf-Private & 2 & 14,29 \\
Campus & 2 & 14,29 \\
Total & 14 & 100 \\
\hline
\end{tabular}

Source: Ministry of National Education, TRNC, Office of Foreign Affairs (2018)

Table 2. Number and citizenship of university students studying in Higher Education sector in TRNC in 20162017.

\begin{tabular}{|lcc|}
\hline Citizenship & Number & $\mathbf{\%}$ \\
TRNC & 13,573 & 15 \\
Republic of Turkey & 52,112 & 65 \\
Vakf- Third World & 27,538 & 29 \\
Total & 93,223 & 100 \\
\hline
\end{tabular}

Source: Ministry of National Education and Culture (2017). 2016-2017 annual statistics. http://eohd.mebnet.net

As shown in Table 2, 93,223 students (\%56) are from Turkey, 27,538 (\%29) are from the third world, and 13,573 (\%15) are from North Cyprus [20].

\section{Education}

Education is the development process of equipping individuals with knowledge, skills, and helping them to adapt to the society. In other words, education is the process through which individuals learn, develop their behaviors, physical and moral cognitive skills, their creativity, ability to solve problems, making decisions and practicing them [29].

Education is a whole process which deals with raising individuals as good citizens with self-respect and respect to the community by adapting new attitudes and behaviors. Educating individuals in social or economic issues is a life-long applied process [13]. It is a change in human caused by physical and societal environment. Education is economically significant because it explains how educational qualities are practiced in the process of production. Another characteristic of educational institutions is that it is for the benefit of the society. Educational institutions are not profit-making organizations, but they turn into investing bodies in order to increase future productivities and outcomes of students. In this respect, schools are professional and expert institutions offering education services.

\section{Economy}

In a broader sense, economy means meeting unlimited human needs with scarce sources. The word "economy" is derived from home economics. As a whole, the industry of a country contributes to service and trade activities. Therefore, sectors are the driving wheels of economy. Economy investigates the choices of people and communities in terms of producing goods for today or for future use with or without spending money. Investments in a country, amount of consumption, and savings form the foundation of economy. When economy is considered in terms of nuclear families, the three factors form the basics. Throughout history, economy developed parallel to the development of communities. The Sumerians established a big scale economy based on money and property, but the first economy was started by the Babylon's and neighboring states [26]. Economy today examines the impact of political events on the country's economy as well as the connection among employment, unemployment, production costs and other changes.

\section{Economic Development}

Economic development has been the concern of all countries for long years and the question of countries with fast and slow economic development has been a discussion point. The main factors determining economic development are: consumed products per head, the rate of literacy, the amount of individual investments and savings, the quality of health services, productivity level per head, the amount of energy consumed by per head, education level of individuals, social life, attitude towards the environment; in short, the level of prosperity. In this respect, the investments, employment, the quality of education offered, and its reflection to the increase productivity, expenditures of university students and the high prosperity of the people affect economic development positively [22].

Economy has always been the biggest concern for all countries. Therefore, they specify short, medium and long-term strategies and put them into practice within certain programs. Parallel to high production and income, there are changes in social, political, and cultural aspects of a country [5]. Economic development is the indication of better life standards 
and the quality of production and services. Therefore, economic prosperity is an important step in quality life standards. At this point, it is important that prosperity and quality life standards are shared by all living in the same economy [2]. Although economic prosperity puts an end to poverty, it should be considered in a wide concept from fair distribution of income to institutionalization of a social state.

- The Theory of Human Capital

The theory of human capital is based on Adam Smith, but it became an important matter of consideration at the end of $1950 \mathrm{~s}$ and at the beginning of 1960s. At this time, economists Theodore and Schultz argued that investments in general and professional education would bring about a long-term return stock of skills and abilities [15]. In a broad sense, human capital is a unit of gained natural abilities and skills of individuals through education. The concept of "human capital" in social meaning was considered and adapted in underdeveloped, developing and developed countries [24]. Today, it is the starting point of information economy in which wide range of researches is done. The emerging of "human capital" is in parallel with social-state concept which prioritize education and analysis it in detail. Upon the adaptation of the "theory of human capital", the expenditures of the social-state in education relatively increased [24].

\section{Economic Growth}

Economic growth is constantly raising the capacity of goods and services produced in a country. It is a constant increase in reel GDP (gross domestic product) in the capacity to produce goods and services. A continuing increase in national GDP is the indication of economic growth and this increase should be permanent, but not temporary [8]. The level of education individuals receive and the information, skills, and intellectual capital stock plays a great role in the development of a country [2]. Success in education is closely associated with human capital stock, which has a crucial role in economic growth. However, there is not a specific measure in this issue.

\section{Education Economy}

Education economy is a branch of science and it examines the effectiveness and productivity of human labor as an input in business as well as its contribution. The logic, in the connection education work, is based on the concept of human capital that raises the productivity aspect of manpower and skills [5]. There is a well-proportioned connection between individuals' quality education levels and education received. An individual's contribution to the economy depends on the education received. The quality level of educational activities affects social, political, and cultural development of people [8]. Investment in education is profitable for both the individual and the people. Education has a significant role in the growth of economy and increase in national income [27]. Mercantilism is the oldest approach that advocates the connection between economic events and the education received by individuals [16]. Education economists commonly focus on the concept of human capital. Based on the increasing industry and trade activities, contributions to economy by well-equipped individuals with knowledge and skills are better understood and this urges countries to consider education more than ever. Mercantilists attributed great importance to human capital as a factor in national income. Considering economic growth, increasing human capital, and raising creative and researcher manpower, education is the priority of countries to survive and compete in today's global world.

\section{The Aim of the Study}

This study aimed at specifying the contributions of the universities and university students in North Cyprus to the economic development, social and cultural structure.

\section{Research Model}

This is a qualitative research to obtain both written and verbal views of the sector representative. It examined the contributions of universities to the economy of North Cyprus and the stakeholders and the effect of university students on social and cultural structure. Qualitative reseaches, as Dogus [11] and Yıldırım \& Şimşek [28] explain is a method through which "observations, interviews, and document analysis is used to reveal perceptions and events in a natural environment realistically and in full. In qualitative studies events are dealt with in detail without any worries about generalization [30].

A case study, one of qualitative models, was conducted in this research. A case study examines a state in real life, in a current context or environment. As Creswell [7] explains, "A case study is a process in which a researcher gathers information about real life, a current system (an event) or multi-confined systems (cases) through observations, interviews, audio-visual materials, documents and reports and sets themes and descriptions". A case study is a kind of designing with both the product and object. In such a study, detailed data are collected through observations, interviews, documents and audio-visual material [28]. 


\subsection{The Participants}

The study group was composed of eighteen expert sector representatives, public organizations and business firms which sell services to university students. A "purposeful sampling" method was used in this research. With this method it is aimed to examine cases from which rich data is thought to be obtained [28]. Every participant was given a code. The coding process is to collect written or visual data in small categories.

\subsection{Data Collection Tools}

The interview form was controlled for reliability and validity by experts in advance. The first section of the form was composed of questions to specify participants' demographic characteristics. The second section included twelve semi-structured openended questions.

As for collecting data, a semi-structured interview form and interview technique was used. The most frequently used data collection methods are observations, interviews, and examining written documents [21]. According to [28] semi-structured interviews are conducted to collect detailed information on a subject. If the responses are not clear and comprehensible, the questions are rearranged so as to be comprehensible. Accordingly, the data were collected through the semi-structured interviews. According to Yıldırım \& Şimşek [28], opinion questions are to specify views about what an individual thinks of a specific event at a specific time. Semi-structured interviews aim at gathering detailed information about a subject. In case of unclear responses, the questions are rearranged for more clarity [6], [28]. Seventy-three percent of said businesses state that they perform production planning; however, it is of consideration that there are only a few utilizing professional management organizations. It is inevitable that said businesses contribute to the sector in case of commencing mass production by overcoming financial deficiencies and adopting a way of increasing their capacities.

\subsection{Data Analysis and Interpretation}

As this is a qualitative research, a content analysis was done to facilitate the description of the data. The content analysis goes through for stages: studying and coding the data, setting themes, arranging and coding themes, defining the findings, and interpreting them [28]. As for describing, classifying, and interpreting the data in codes and themes, the first step is to start with short notes of reading and reminding and then defining the data, classifying and interpreting. Setting codes and categories is the basis of qualitative data analysis [7]. The researchers can interpret in the light of their views and the different views literature. The participants were represented by codes such as P. 1, P. 2, and P.3 etc.

\section{Research Findings}

\section{The Contribution of the Universities and University Students to Economic Development of the Island}

Almost all the participants agreed that the universities and the added value provided contributed to the economy in several ways. Foreign students are the source of income for many sectors, which directly or indirectly affect economy and economic development positively.

\section{The Population Ratio of the Universities and University Students and their Contribution to Economic Development}

The one thousand university students compose $1 / 3$ of the population $(300,000)$ of the island. As it can be seen in Table 2, \%56 of them is from Turkey and $\% 29$ is from the third world countries. The big majority of the participants admitted that university students had a big share in the population of the country. Several big and small sectors benefit from them by providing accommodation, food, transportation facilities etc., and this turns into a big contribution to the economy and economic development on the North Cyprus.

\section{The Effect of University Students on Social and Cultural Structure of the North Cyprus}

Most of the participants stated that the foreign students did not spoil the social and cultural structure of the island. On the contrary, they created a cultural richness.

Some participants expressed, due to the bad economic conditions in their countries that some foreign students may wish to stay and be employed on the island, which, in due course, may affect the social and cultural structure negatively.

\section{State Subsidy in Higher Education Sector}

It was revealed in this research that more than half of the sector representatives complained that the State contribution to higher education sector and the grants for the students were limited. A small number of the respondents advocated that the State contribution was sufficient. Similarly, a small number explained that they had no idea about this issue. 


\section{Discussion}

In a study, Keskin (2011) [17] emphasized Governments' responsibilities in developing economy to raise people's prosperity. Economic development is dependent on instigating the dynamics underlying development. One of these dynamics is technology, which is a factor for better outcomes for development when used in production processes. At this point, Keskin pointed out that technological production was achievable only through human capital, which has similarities with the social indications in developed countries. High level of education, longer average of life expectancy, and brain drain among countries are common characteristics of countries with high level prosperity. It is assumed that, the role of human capital has a great role in these common characteristics. Human capital is greatly dependent on education and all the expenditure in education is a kind of investment. Keskin [24] added that university education should be expanded to wider mass, the capacity should be increased, new universities should be established, the servants' qualifications should respond to the needs, there should be in-service training for the betterment of qualifications, and women should be involved in the process to join the workforce. In the same study, he came up with another finding and explained that in order to constitute an investment quality and the education to constitute a capital quality, qualified manpower to meet the needs of economic development should be raised. This statement draws attention to the education an individual receives and economic development. These findings by Keskin are parallel to the ones in this research.

Kingsley, (2019) [25], describes the concept, nature, types of learning facilities, the need for learning facilities in the school and facility management methodologist. It recommended among others that school managers and teachers who constantly use learning facilities are to be given orientation on the maintenance of such facilities.

Joyami \& Salmani [16] developed five hypotheses, which include the effect of students' trust in the university, the university's commitment to the student, the relationship between the university and the students on the perceived value, the perceived value by student on satisfaction and the students' satisfaction on loyalty. Öztürk et al. (2011) investigated the contribution of universities in Anatolia to socio-economic and socio-cultural structures of the area. They pointed out that the contributions from these universities, determined the financial bases of the development of the cities as well as their socio-cultural structure. Adding to their arguments, they stressed that in order to increase the contributions and lead the people, universities should be established in cities with fully completed infrastructure [23].

Low quality education and inadequacies in the physical, socio-economic, and socio-cultural structure of the city will decrease the contribution of the universities to the city [18].

[15] in a study "The Impact of Universities in Turkey to Urbanization" investigated the impact of 24 universities on population growth and migration characteristics in the cities they were established. For some reasons, nine of the universities were exempted from this study. The study revealed that in a great many of the fifteen cities with universities, the decreasing annual population growth between 1975and 1990 showed a significant rise in 1990. Parallel to this, there was an increase in migration to these cities, and this contributed to the economy. Işık [15] investigated the impact of universities in terms of social culture and demographic characteristics in the cities and found out that there was an increase in the population of these cities. This research dealt only with social, cultural, and economic issues and revealed that university students did not affect social and cultural structure of North Cyprus up to the present time, which indicate that a change in the demographic structure has not been observed, but universities have positively affected the economy of the cities.

\section{Conclusion}

\section{The Contribution of Universities and University Students to the Economic Development of North Cyprus}

The portion of contribution of the university students to the economy of North Cyprus in terms of GDP is around \%28 [14]. This study revealed that, from the very first day of their establishment, the universities contributed significantly to the economic development of North Cyprus, particularly the stakeholder sectors such as transportation, markets, restaurants, accommodation, hair-dressers, and communication and the tradesman. According to the statistics, there are about 100,000 students, $85 \%$ from other countries, in North Cyprus and the flow of money from other countries contributes a lot to the economy and economic development.

$100 \%$ of the participant representatives of nongovernmental organizations and state-ownedeconomic enterprises admitted that the universities and students operating in North Cyprus contributed to the economy and tradesman and small and big enterprises positively. The participants also stated that investment by universities and the educated manpower was another factor with a positive contribution to the economic development. 


\section{The Proportion of Universities and University Students in the Population of the North Cyprus and their Impact on the Economic Development}

The proportion of university students composes $1 / 3$ of the population and this is considered to be quite high compared to the total population. $85 \%$ of the students come from different countries and provide a high cash flow into the country, which affects the economy, sectors and economic development.

\section{The Impact of Foreign University Students on the Social and Cultural Structure of the North Cyprus}

When the number of students at universities is considered, it can be seen that a big majority of them come from abroad. In spite of this reality, there has not yet been any negative impact on the social and cultural structure of the island. On the contrary, they created a rich cultural variety. However, employment of these students in various jobs, particularly the ones from the third world, may affect the social and cultural structure of the North Cyprus in the long run.

\section{The Contribution by the State to Higher Education}

It has been observed that the contribution by the state to the universities and the grants provided for the students is quite limited.

\section{Suggestions}

- The level of contribution of universities and university students to economic development and sectors in North Cyprus cannot be ignored. Therefore, not only in Turkey, but in other overseas countries and educational fairs marketing universities in coordination with Foreign Offices of the Republic of Turkey should be a priority. In addition, for the sustainability of the sector and receive feedback, the graduates and their employment issues should be closely followed.

- In order to provide better services for the students and other customers and increase production, the personnel in the sectors either graduates or not or coming from foreign countries should receive training in collaboration with the Ministry of National Education, the Ministry of Labor and Social Security, private sectors and universities through different programs. The successful personnel in these educational programs should be awarded certificates.

- In this study and other studies done in different countries, emphasize was put on educational economy and Human Capital Theory and the factor of educated personnel in economic development of the country. In this respect, longterm strategies for the future of the education sector should be considered with all the involved sectors. These plans and strategies should become a state policy and more resources should be allocated for investment related to education and the development of the sector.

- In the light of all the findings, the state should focus on economic and sectoral development within certain bounds. Strategical plans should be made for economic growth, put in practice, consider security and health issues, and they should have a vision.

- In order to improve the current situation and intake more students, parallel to student satisfaction, all the services provided for the students should be reconsidered in terms of meeting the students' economical and quality needs. This issue is as important as the education students receive. Therefore, it should be examined in detail.

\section{References}

[1]. Al-Bataineh, A. T., Brenwall, L., Stalter, K., \& York, J. (2019). Student growth through goal setting. International Journal of Learning and Teaching, 11(4), 147-161. https://doi.org/10.18844/ijlt.v11i4.4329

[2]. Baykan, H. (2018). Sektör yöneticilerinin yükseköğretim alanında ekonomiye yönelik görüşlerinin değerlendirilmesi (Doktora tezi, Yakın Doğu Üniversitesi).

[3]. Baykan, H., \& Uzunboylu, H. (2018). Administrator's Management Preferences and Management Theories. IIOAB Journal: A Journal of Multidisciplinary Science and Technology, 9(3), 2129.

[4]. Dagnew, A., Yirdaw, A., \& Asrat, S. (2020). Challenges that contribute to low participation of women in educational leadership at government primary schools, Ethiopia: Women Educational Leadership participation. Contemporary Educational Researches Journal, 10(3), 109-122. https://doi.org/10.18844/cerj.v10i3.4968

[5]. Carnoy, M. (1995). Benefits of improving the quality of education. International Encyclopedia of Economics of Education, 2, 154.

[6]. Colak, M., \& Cetin, T. (2019). Activity situation analysis for production of furniture businesses. Global Journal of Business, Economics and Management: Current Issues, 9(1), 1-7. https://doi.org/10.18844/gjbem.v9i1.1352

[7]. Creswell, J. W., \& Creswell, J. D. (2017). Research design: Qualitative, quantitative, and mixed methods approaches. Sage publications.

[8]. Çakmak, Ö. (2008). Eğitimin Ekonomiye ve Kalkinmaya Etkisi. Dicle Üniversitesi Ziya Gökalp Eğitim Fakültesi Dergisi, (11), 33-41. 
[9]. Dedeçay, S, S. (1983). Aslı nedir. Lefkoşa Özel Türk Üniversitesi Yayınları. 3. Baskı. Lefkoşa: Kıbrıs Postası Of-Set Matbaası.

[10]. Demirel, M. V., Türkel, A., \& Aydin, I. S. (2020). Speaking Self-Efficacy Beliefs of Turkish University Students. Cypriot Journal of Educational Sciences, 15(3), 399-411. https://doi.org/10.18844/cjes.v15i3.4905

[11]. Dogus, Y. (2019). A qualitative research on organizational peace in schools. Cypriot Journal of Educational Sciences, 14(4), 661-675. https://doi.org/10.18844/cjes.v11i4.4486

[12]. Ferreira, M. M., \& Oliveira, S. R. M. (2020). Integrated framework for strategic cost management based on target costing, ABC, and product life-cycle in PDP: Empirical experience. Global Journal of Business, Economics and Management: Current Issues, 10(1), 31-43. https://doi.org/10.18844/gjbem.v10i1.4700

[13]. Georgiadis, M. N. (2007). Educational reforms in Greece (1959-1997) and human capital theory. Journal for Critical Education Policy Studies, 5(2), 342-368.

[14]. Gökçekuş, H. (2015). KKTC Başbakanlık Yükseköğretim ve Strateji Belgesi ve Eylem Planı. Lefkoşa: KKTC Devlet Basmevi.

[15]. Işık, Ş. (2008). Türkiye'de üniversitelerin kentleşme üzerine etkileri. Dokuz Eylül Üniversitesi Sosyal Bilimler Enstitüsü Dergisi, 10(3), 159-181

[16]. Joyami, E. N., \& Salmani, D. (2019). Value creation for students using the communication marketing approach at Tehran University. New Trends and Issues Proceedings on Humanities and Social Sciences, 6(7), 88-100. https://doi.org/10.18844/prosoc.v6i7.4517

[17]. Keskin, A. (2011). Ekonomik Kalkinmada Beşeri Sermayenin Rolü Ve Türkiye. Atatürk Üniversitesi Iktisadi ve İdari Bilimler Dergisi, 25(3-4), 125-153.

[18]. Kingsley, O. V. (2019). Management of learning facilities. New Trends and Issues Proceedings on Humanities and Social Sciences, 6(7), 82-87. https://doi.org/10.18844/prosoc.v6i7.4516

[19]. KKTC Milli Eğitim ve Kültür Bakanlığı. 2016-2017 İstatistik yıllığı.

Retrieved from:

http://eohd.mebnet.net/sitesi/defaul/files/20162017 201701.pdf [accessed: 15 July 2020].

[20]. KKTC Milli Eğitim ve Kültür Bakanlığı. (2018). Yüksek Öğrenim ve Dış İlişkiler Dairesi.
[21]. Koc, E. S., \& Ontas, T. (2020). A Comparative Analysis of the 4th-and 5th-Grade Social Studies Curriculum According to Revised Bloom's Taxonomy. Cypriot Journal of Educational Sciences, 15(2), 292-304. https://doi.org/10.18844/cjes.v15i2.4799

[22]. Kutlu, H. A. (2009). Entellektüel sermaye: Türkiye muhasebe sisteminde raporlanabilir mi?. Hacettepe Üniversitesi Iktisadi ve İdari Bilimler Fakültesi Dergisi, 27(1), 235-257.

[23]. Öztürk, S., Torun, İ., \& Özkök, Y. (2011). Anadolu'da Kurulan Üniversitelerin İllerin SosyoEkonomik Yapılarına Katkıları/Contributions Of Universities Established In Anatolia To The SocioEconomic Structure Of The Cities. Mustafa Kemal Üniversitesi Sosyal Bilimler Enstitüsü Dergisi, 8(16), 145-158.

[24]. Savarese, G., Pecoraro, N., Fasano, O., Mollo, M., Iannaccone, A., Manzi, F., \& Curcio, L. (2019). Perceived social support and clinical symptomatology in Italian university students. Global Journal of Guidance and Counseling in Schools: Current Perspectives, 9(3), 90-94. https://doi.org/10.18844/gjgc.v9i3.4121

[25]. Stosic, L., Dermendzhieva, S., \& Tomczyk, L. (2020). Information and communication technologies as a source of education. World Journal on Educational Technology: Current Issues, 12(2), 128135. https://doi.org/10.18844/wjet.v12i2.4815

[26]. Türk, A. (2014). Ekonomi. İstanbul: Kafekültür Yayıncilık.

[27]. Vanichvatana, S. (2020). Who Uses Home as Informal Learning Spaces: A Bangkok Private University Case Study. World Journal on Educational Technology: Current Issues, 12(1), 37-47. https://doi.org/10.18844/wjet.v12i1.4416

[28]. Yıldırım, A., \& Şimşek, H. (2013). Sosyal bilimlerde nitel araştırma yöntemleri. Seçkin yayıncılık.

[29]. Yehya, F. M. (2020). Promoting TechnologyImplementation Learning paradigm for online learning in secondary Education. Global Journal of Information Technology: Emerging Technologies, 10(1), 12-21. https://doi.org/10.18844/gjit.v10i1.4620

[30]. Safaryan, N. (2020). Methodological issues of education monitoring and evaluation. International Journal of Learning and Teaching, 12(4), 176-183. https://doi.org/10.18844/ijlt.v12i4.4615 